\title{
TOWARD A MULTICULTURAL ECOLOGY
}

\author{
ADRIAN IVAKHIV \\ University of Wisconsin-Oshkosh
}

The debate between realists and constructivists has polarized environmental scholarship in recent years. Situating this debate within the longstanding modernist tradition of categorically distinguishing "nature" from "culture," and the natural sciences from the social sciences and humanities, this article suggests that we need to find a non-dualistic space for rethinking cultural-ecological relations. Such a space has been articulated by actor-network theory (ANT), but this theory leaves significant gaps in its understanding of agency and of macro forces. To fill in these gaps, the author draws on perspectives that theorize perception and agency as embodied, animate, and ecologically embedded and that theorize macro forces as discursively shaped and causally multidirectional and multiscalar. The author proposes the concept of multicultural ecology as a way of articulating the indivisibility of nature and culture and the multiplicity of cultural-ecological practices, and suggests a normative dimension by which such practices can be compared and evaluated.

$\mathrm{T}$ he debate between realists and constructivists has polarized much environmental scholarship in recent years. Although social constructivist accounts have proven fruitful in making sense of a wide range of social phenomena, their more recent application to natural phenomena, and especially to environmental issues, has raised questions that prove discomforting for many environmental scholars and activists. The dilemma raised by constructivists is this: If nature, wilderness, ecology, and the environment are all socially constructed-ideas about the world rather than the world itself-what is it exactly that environmental protection efforts are fighting to defend and preserve? ${ }^{1}$

This debate flared up among environmental scholars following the publication of William Cronon's (1995a) article "The Trouble With Wilderness" and the edited collection Uncommon Ground (Cronon, 1995b). Although not an entirely original argument (see, e.g., Callicott, 1991; Nelson, 1996), Cronon's cultural and historical deconstruction of the wilderness idea managed to make it into the popular press, with an excerpt published in The New York Times. In a series of articles and magazine editorials, conservation biologist Michael Soulé (1995), Earth First! cofounder Dave Foreman (1996/1997), biocentric deep ecologists George Sessions (1995a, 1995b, 1996) and Paul Shepard (1995), and poet Gary Snyder (1996/1997, 1998) responded by decrying Cronon and his postmodern deconstructionist allies as new enemies of environmentalism, responsible for what Soulé and Lease (1995) called a "social siege of nature" that ostensibly both parallels and supports the physical siege of nature by industrial society. ${ }^{2}$

Organization \& Environment, Vol. 15 No. 4, December 2002 389-409

DOI: $10.1177 / 1086026602238169$

(C) 2002 Sage Publications 
Although some of these critics' arguments could be explained as a defensive reaction against a perceived territorial incursion by humanities and social science scholars onto their environmental conservationist turf, a more serious criticism underlies their reaction. This criticism points at a perceived contradiction in poststructuralist or postmodernist accounts of nature. ${ }^{3}$ Although poststructuralist critics claim to deconstruct the dichotomous discourses of modernity - such hierarchical binaries as male/female, White/Black, light/dark, hetero/homo and mind/ body, a careful review of their writing shows the persistence of a more deeply ingrained binary: that according to which humans, as bearers of language and discourse, culturally construct the world (whether as active agents or as passive conduits of text or discourse), whereas nonhuman nature remains mute, nondiscursive, and passive. In a critique of the constructivist perspective on nature, Peterson (1999) summarized this view: "Humans possess a special status in the universe, ... because of our own literally supernatural capacity, through discourse and symbolic practice, to invent and give meaning to both ourselves and the world" (p. 350). One could argue that a more genuinely postmodern ontology should reject this construct along with the others as another dualism that privileges some (in this case, humans) over others (nonhumans). ${ }^{4}$

Critical of the anthropocentrism that seemingly underlies the social constructionist position, many environmentalists reverse the valences of the nature-culture dichotomy and posit the opposite, arguing for a biocentric view of nature as the source of values, to be revered, emulated, and restored to its rightful position over a prodigal humanity. Celebrating a wild nature that is pure and untainted by humans over a human social world that is tame, corrupt, or fallen constitutes a reversal that many argue is bound to fail (except, perhaps, to the extent that it might be a merely situational act of strategic essentialism) because it leaves intact the dichotomy that is the root of the problem (e.g., Latour, 1993; Vogel, 2002). Both the cultural triumphalist and the return-to-nature positions presume an essentialist nature that is earlier than and prior to culture. Both follow a logic of priority (nature's) and overcoming (culture's), diverging only in whether they celebrate or lament this event of overcoming. Nonhumans, in either case, remain on the other side of the boundary from humans, who are presumed to be, for better or worse, the cultural species.

Overcoming this conceptual dualism can hardly be a simple task, as it would require unraveling the binary and arriving at something barely imaginable from within the dualistic modernist paradigm. Haraway (1991, 1992), Latour (1993), Hayles (1991, 1995), Deleuze and Guattari (1987), Serres (1981) and others have proposed a series of images - of hybrids, cyborgs, coyotes, quasi-objects, networks, assemblages, rhizomes, and the like-specifically intended to unravel such a binary. Although they are valuable as evocations of the sense of boundary blurring, these images in themselves barely begin the process of analytically reconstructing cultural-ecological relations. Other authors have begun to speak of a "social nature" according to which each of nature and society are "continuously constituted through the other" (Braun \& Castree, 1998, p. 34). Yet as Braun and Castree's $(1998,2001)$ two recent volumes indicate, the forms this coconstitution takes remain as multiple as the analytical lenses brought to study them. Contributions to such a reconstructive endeavor can be found scattered across a range of disciplines, including political ecology (e.g., Escobar, 1999; Peet \& Watts, 1996), environmental history and historical ecology (Crumley, 1994), environmental anthropology (Crumley, 2001; Descola \& Pálsson, 1996; Ellen \& Fukui, 1996), environmental sociology (Redclift \& Woodgate, 1998), human ecology (Steiner \& 
Nauser, 1993), dialectical biology (Levins \& Lewontin 1985), biocultural anthropology (A. H. Goodman \& Leatherman 1998), and related fields.

Although most of these efforts advocate some sort of relational, interactive, or dialectical understanding of nature and culture, the vast majority remain vulnerable to the criticism that they retain the same basic underlying dualism. For instance, even as deeply probing and broad-ranging an effort as Escobar's (1999) "antiessentialist political ecology" defines itself as "the study of the manifold articulations of history and biology and the cultural mediations through which such articulations are necessarily established" (p. 3, italics added). Eschewing the nature-culture dualism, Escobar ended up simply deferring to another pair of terms, history and biology (or "the biophysical"), with a third term, culture, mediating between the two, as if it is the latter that is the active agent between the otherwise preexistent duality (cf. Milton, 1999). Similarly, the numerous efforts to study the nature-society, or ecology-economy, dialectic in world-historical terms (e.g., Moore, 2000) presuppose that the two begin as ontologically distinct domains, with no cultural content in the first and no biological in the second. This problem of residual dualism has been critiqued and addressed in various ways (e.g., Ingold, 2000; Lewontin, 1982; Oyama, 2000), but the task of building up a complex model of political, economic, cultural, ecological, and biological relations remains far from accomplished.

This article contributes to the project of developing a nondualistic understanding of nature and culture but takes as its starting point the premise that the dichotomy between nature and culture must be refused and subverted at the outset. Failure to make such a move unduly complicates the task of clearly thinking our way out of our current political-ecological predicaments. In what follows, I begin by locating a provisional neutral ground between the natural and social sciences and thus between the rival domains that have carved out the intellectual authority over the two respective realms of nature and society. Specifically, I will begin from the space that has been staked out, not uncontentiously, by the research program known as actor-network theory (ANT), an approach closely associated with anthropologists and sociologists of science Bruno Latour, Michel Callon, John Law, and a growing alliance of others. Although ANT has been critiqued on several counts during the two decades or so since its emergence, it has demonstrated a robust capacity for responding to criticisms, revising its terms, and entering into an increasing variety of fields of application, ranging from science and technology studies to organizational management, economics, and environmental studies. My reasons for beginning with ANT are threefold: (a) because ANT explicitly sets out to clear the slate of nature-culture dualism and instead to treat all entities symmetrically so that their interactive network relations can be better appreciated; (b) because one must begin somewhere-preferably in the thick middle of things - and whereas other practiceoriented approaches (such as Pierre Bourdieu's sociology of practice or poststructuralist notions of 'performativity') share a focus on the dynamism of the social world, they rarely show an interest in treating the nonhuman and artifactual worlds as similarly dynamic and active; and (c) because its use by geographers, sociologists, and others studying environmental issues, especially those related to the social construction of nature debate, has been growing in recent years, with positive assessments coming from numerous quarters (e.g., Bingham, 1996; Braun \& Castree, 1998, 2001; Busch \& Juska, 1997; Castree, 2002; Eden, Tunstall, \& Tapsell, 2000; D. Goodman, 2001; Hetherington \& Law, 2000; Murdoch, 1997, 2001; Parker \& Wragg, 1999; Swyngedouw, 1999; Whatmore, 1997, 1999). 
On its own, however, ANT's scope is arguably too limited for the purposes I have laid out, and so I proceed from its neutral ground by building upward and outward in two general directions. First, I address the critique that ANT, while avoiding anthropocentric assumptions about agency and the motivations underlying action, flattens and squeezes out any psychological complexity from its notion of agency. Thus, I draw on perspectives that theorize agency as embodied, animate, and ecologically embedded (specifically, Maturana and Varela's enactive biology of cognition, J. J. Gibson's ecological psychology, and the "dwelling" perspective of anthropologist Tim Ingold). Then, to be able to encompass the complexity of macro processes while simultaneously drawing out generalizations across diverse such processes, I bring in theoretical perspectives that treat these as highly differentiated, discursively shaped, and causally multidirectional and multiscalar (historical ecology, political ecology, and certain forms of environmental anthropology and sociology). In the process, I develop the concept of a multicultural ecology-a perspective that acknowledges the cultural embeddedness of any and all ideas of nature, accepts the coexistence of multiple cultural-ecological practices, and suggests, at least in a preliminary way, a normative dimension by which such practices can be compared and evaluated. My ultimate goal is to suggest some unexplored connections between disparate fields that may contribute to a nondualistic model of human-environmental relations, a model that can aid in the task of developing more appropriate ecological practices for a postmodern, pluralistic, and cosmopolitan world.

\section{UNDOING DUALISMS: BEGINNING FROM THE MIDDLE OF THINGS WITH THE ACTOR NETWORK THEORY}

The conceptual separation of the world into mind and matter-res cogitans and res extensa, in the terms of René Descartes—disjoins subject from object, locating reason and meaning in the brain or mind, the seat of subjectivity and reason, leaving the nonhuman world seemingly devoid of these capacities. In this now all too familiar picture, human agency and subjectivity are assumed to be located in the minda "mind in a vat," as Bruno Latour and Donna Haraway have coyly described itcounterposed against a basically dead, mechanical world of objects (also see Merchant, 1980, 1998). A parallel dichotomy underpins the modern idea that things natural and things cultural constitute two different orders of reality, with humans on one side of the boundary and nonhuman animals (and everything else) on the other. Underpinning the scientific worldview, these two dichotomies together supposedly demarcate an object world that can be studied dispassionately and objectively from the world of human interests, values, and judgments.

The nature-culture dualism has in turn given rise to the basic intellectual division of labor in academia, that between the natural sciences and the humanities and social sciences. As Latour (1993) argued in We Have Never Been Modern, this division of labor works well enough as long as the "hybrid" real world does not assert itself too strongly. The problem is that this conceptual dichotomy has itself been historically set into practice in ways that have intensified the production of naturaltechnical-social-discursive hybrids, entities that elude analysis as either merely natural or fully cultural. Phenomena like global climate change, ozone holes, AIDS and other viruses, genetic and reproductive technologies, and so on, are merely the latest in a long line of phenomena that cannot be fully understood from within the segregated vantage points of either scientific realism or social constructivism. Because these "imbroglios" are "simultaneously real, like nature, narrated, like dis- 
course, and collective, like society" (Latour, 1993, p. 6), understanding them requires transdisciplinary efforts, the epistemological underpinnings of which are yet to be fully worked out.

The debate over the social construction of nature is a clear instance of this dichotomy - an updated version of C. P. Snow's "two cultures" —at work. On one side, realists insist that there really is a natural world and that we can come to know it objectively through the tools of science and reason. On the other side, constructivists maintain that the very concepts we use to make sense of the world (e.g., nature, environment, wilderness, ecology, gender, race) are social constructs emerging out of particular (Western, Eurocentric, colonial, male-dominated) histories and heavily imbued with power-laden cultural assumptions.

As historians of science have amply demonstrated (e.g., Gieryn, 1999), the division of labor between those who study objective nature and those who study human culture has always been tenuous and contested. In their attempts to explain the social by recourse to the natural, for instance, such research programs as Darwinian biology, behaviorist psychology, cybernetics, and sociobiology have been perceived by social scientists as attempts by natural scientists to colonize the terrain of the social. On the other side of the fence, the history of social anthropology has been marked by efforts (on the part of Alfred Kroeber, Franz Boas, and others) to carve out a sphere - the cultural-that would be safely protected from the "intellectual imperialism" of the natural sciences (Horigan, 1988; McGrane, 1989). In recent years, however, social constructivism has itself been seen by natural scientists as a form of colonization of the natural by those who are supposed to study the social (e.g., Gross \& Levitt, 1994; Gross, Levitt, \& Lewis, 1996).

The risk, then, in attempting to study hybrids is that one of the two dominant intellectual optics of the late modern era-the natural-scientific or the sociocultural — will dominate or negate the other. Working our way out of this realist/constructivist (and naturalist/culturalist) conundrum may therefore require finding an in-between space in which reconceptualization might be able to proceed on neutral and nondualistic terms. But is such a neutral space possible? Constructivists would argue that it is not, because all forms of inquiry are socially and historically situated. Given the nature of the debate, however, it may be that an objectively neutral space is neither necessary nor possible; rather, what is required may only be a provisional space of relative neutrality from which our rethinking can begin.

The research program that has most explicitly tried to develop a neutral vocabulary for the nature-culture imbroglios that make up the world has been ANT. Actor-network theorists have taken as their task the attempt to redescribe and analyze real-world phenomena in terms that are not dependent on a priori ontological distinctions between classes of actors or agents as, for instance, inherently active or passive, agents or nonagents, cultural or natural, subjects or objects. Rather, they assume that "entities take their form and acquire their attributes as a result of their relations with other entities" (Law, 1999, p. 3), that is, as effects and outcomes of action and practice. The task of the theorist is to determine how it is-through what relational interactions and practices - that actantial networks arise and change and that entities achieve durable forms. ANT's method for doing this is to follow the actors so as to trace the chains of connection between the nodes that make up the networks. ${ }^{5}$

ANT thus views the world as consisting of heterogeneous and dynamic networks that are constantly being made and remade through practice. This focus on practice is one that ANT shares with other processual approaches, such as those of Bourdieu or of the more performative and materialist variants of poststructuralism 
(e.g., Judith Butler, Deleuze and Guattari, Laclau and Mouffe). In their efforts to avoid essential categories such as those of nature and culture, actor-network theorists have developed a new vocabulary, a "symmetrical metalanguage" (Callon \& Latour, 1992, p. 354) or "infralanguage" (Latour \& Crawford, 1993a, p. 250). Using this language, they describe a world made up of contingent and emergent networks, always in process, in which causality and agency are distributed through practices of mobilization, translation, negotiation, and enrolment (rather than discovery), in which ontologically realist terms such as proof and data are substituted for by functionally descriptive terms such as inscriptions and immutable mobiles, and in which actors are replaced by ontologically neutral actants. This latter term, borrowed from semiotics (and denoting anything that could be said to fulfill the function of acting), serves as a good example of ANT's ontological agnosticism concerning species. Callon and Latour (1992) recognize "nonhumans" to be "party to all our disputes," but "instead of being those closed, frozen, and estranged thingsin-themselves whose part has been either exaggerated or downplayed," once all a priori distinctions between the natural and the cultural are abandoned, they become "actants-open or closed, active or passive, wild or domesticated, far away or near, depending on the result of the interactions" (p. 355). The distribution of "actantial roles" and "competences" between humans and nonhumans thus remains open and negotiable in real-life interactions that "secrete" "natures" and "societies" (among other things) as their "by-products" (p. 349). "The very notion of culture," Latour (1993) wrote, "is an artifact created by bracketing Nature off. Cultures-different or universal-do not exist, any more than Nature does. There are only naturescultures" (p. 104). Similarly, ANT's focus on the intermediary realm of network building results in the replacement of the dichotomy "material reality/discursive representation" with the notion of "chains of translation," a term that refers to the variously interconnected forms of mediation by which "actors modify, displace, and translate their various and contradictory interests" (Latour, 1999, p. 311). ANT thus focuses on identifying the specific kinds of "translations" by which materialdiscursive networks are built and strengthened, giving rise to the phenomena of which we know and speak, whether these be pasteurization (Latour, 1988), anemia (Mol, 1999), ecologically restored rivers (Eden, Tunstall, \& Tapsell, 2000), or public transit systems (Latour, 1996a). In its goal of providing “ 'thick' descriptions of the assembly, coordination and durability of powerful networks," arguably, not only has ANT contributed a more fine-tuned approach to understanding the place of nonhuman organisms and artifacts in human social arrangements; it has also, as D. Goodman (2001, p. 195) suggested, provided "conceptual tools to understand how these 'translation regimes' might be dismantled."

Of the critiques of ANT, those most relevant to the present article pertain (a) to its "ontologically flattened" conception of agency (Laurier \& Philo, 1999), with all agents characterized as potentially equivalent, "anonymous, ill-defined and indiscernible" (Callon, 1999, p. 182), and (b) to its apparent difficulty (despite the aforesaid) with understanding and critiquing obdurate asymmetries, especially largescale structural asymmetries, of social power. ${ }^{6}$ In terms of the first, being unwilling to ascribe any initial motivations, intentions, or interests to actors, actor-network theorists have tended to fall back onto a kind of bare-bones Machiavellian or Nietzschean model of strategies and tactics. Actants are said to mobilize other actants to build and strengthen their networks (in which they themselves are centrally situated), but their motivations for doing so are left unaccounted. The social psychology of ANT, according to critics, is thereby rendered thin and homogeneous, with little appreciation for different kinds of actants, variable modalities of 
action, and different ways in which action can be enabled or constrained. With regard to the second critical point, ANT's focus on networks and following the actors has often led to a bias in favor of actors that are centrally located within networks, and against those that are systematically marginalized. According to critics, then, ANT's methodological principle of generalized asymmetry leads to a loss of normative positioning such that it is unable to provide effective critical analyses of large-scale structures and power asymmetries, such as those of capitalism, patriarchy, racism, or colonialism. Though all of these issues have been addressed and variously debated by ANT's supporters and critics, I will, in what follows, suggest a few moves by which these broad gaps could be filled in and fleshed out more substantively through alliance with other research programs, yet without abandoning ANT's project of deconstructing the nature-culture dualism. I will begin by suggesting that we move down to the level of organismic biology and psychology, the realm of embodied action; then proceed outward to a more complete appreciation of organism-environment interaction; and finally open up to the level of culturalecological and socio-techno-economic systems writ large.

\section{FILLING DOWN AND OUT: SUBJECTIVITY, EMBODIED ACTION, AND ECOLOGICAL RELATIONALITY}

ANT's challenge to the human-nonhuman boundary is consistent with the various critiques of universalist, especially liberal individualist, notions of the human subject. ${ }^{7}$ Subjectivity, according to critics of liberal humanism, is not a pregiven essential substance, nor is it necessarily tied to Western notions of rationality and individuality. Rather, it is fluid, multiplicitous, always in process, shaped within discourses and relations of power, and formed through collective and individual action. Rejecting a reified liberal individualist model of the subject, posthumanist theorists gravitate toward other sources of understanding subjectivity, such as the body and desire (both of which humans clearly share with other living organisms), performance, discourse, and identity. Following ANT's questioning of the species barrier, it becomes possible, and perhaps necessary, to ask what agency may mean at the organismic, bodily, and interindividual levels-a question that has been addressed on the other side of the nature-culture line by biologists studying animal behavior and cognition. Although a humanist would shy away from approaching this boundary, a posthumanist and nonanthropocentric critical ecology would seem to have little recourse but to engage with it.

Among biologists grappling with the question of defining life in a nonmechanistic manner, Chilean emigrés Humberto Maturana and Francisco Varela $(1980,1987)$ stand out as having developed a coherent and influential theoretical model. In their theory of autopoiesis, or self-organization, Maturana and Varela conceive of living systems as self-organizing, autonomous entities that actively maintain themselves through a history of "structural coupling" with their environments. Much of Maturana's and especially Varela's work in the past few decades has been in the realm of cognition, where their "enactive" cognitivism has challenged the dominant representationalist model of cognition (e.g., Varela, Thompson, \& Rosch, 1991). According to representationalists, thinking organisms create mental models or representations (in their brains or minds) of the outside world and process the information given in these models—all in a manner not very different from how computers process information. In contrast, enactive cognitivism sees cognition as a circular process rooted in an organism's embodied actions in relation to its domain of involvements; it is the ongoing process of bring- 
ing forth a world (not the world, but $a$ world for the organism). Action therefore emerges out of a subjectively constructed and experienced world in a manner not unlike that described by ethologist Jakob von Uexküll (1957): "As the spider spins its threads, every subject spins his relations to certain characters of the things around him, and weaves them into a firm web which carries his existence" (p. 14).

Von Uexküll's depiction of the spider's subjective world bears a striking resemblance to anthropologist Clifford Geertz's (1973) description of the human as "an animal suspended in webs of significance he himself has spun" (p. 5). For Geertz, those webs are made of cultural and linguistic meanings, but for both von Uexküll and Geertz, these subjective worlds or Umwelten connect and interpenetrate with others to create intersubjectively shared worlds. Reality, in other worlds, is constructed not only by humans but by all embodied organisms, through the interactions by which they maintain themselves, their relations, and their worlds. Perceptual and interpretive activities lie at different points along a continuum of means by which these worlds are coconstructed through embodied action. Action, in this sense, is not only abstractly cultural but is relational, including the full continuum of perceptual and communicative activities found among living organisms. An appropriate word to designate this would be animacy. Like the words animal and anima, animacy is etymologically rooted in the words for air, breath, soul, and aliveness, and as such it may serve as an appropriately evocative challenge to the mechanistic model of the world that many environmental theorists have long critiqued. Unlike society or culture, both of which have their ready opposite in the idea of nature, animacy bridges the gap between human and nonhuman organisms. One could argue that this notion of animacy merely displaces the nature-culture boundary onto the distinction between animate organisms and inanimate objects. This extension alone should perhaps be seen as a gain rather than a loss, but my intent is not to settle for such a shift. It is rather to incorporate a more organismically and ecologically embodied notion of agency into the broader framework of relational networks-networks built up from organic and inorganic elements in and through which animate agency circulates (as opposed to its being a fixed property of individuals).

Both animacy and the notion of cognition as embodied action crucially point to the relations between organisms and their environments. To fill out this area, we can look to the work of J. J. Gibson and his associates in ecological psychology. Gibson was a psychologist of perception. In a series of works (Gibson, 1979, 1982), he developed the theoretical basis for what he called "ecological psychology." In this work, he tried to explain how animals (and humans) perceive their environments, but he tried to do this without recourse to either the subject-object dichotomy or the representationalist model of perception. Gibson argued that organisms are so constituted, and live in a world so constituted, that they do not need to create representations "inside their heads" of an "outside world." Rather, the "information" they need to survive and to thrive is found in the world, given directly in the form of what Gibson called "affordances." Affordances are the "properties of an object that render it apt for the project of a subject" (Ingold, 1992, p. 42). They exist as inherent potentials of objects, that is, as opportunities for action in the environment of an organism. As such, they can be taken as the "analytical units of embodiment" making up the "entire universe of potential action" for a situated actor (Sanders 1999, p. 135). For instance,

a relatively horizontal, rigid, extended surface approximately knee-height of the ground is "sit-on-able" to a creature with the dynamic capability of maintaining 
balance while lowering its centre of mass until the buttocks are supported by the surface. To the same creature with the intention of reaching something high, the same surface layout might afford stepping on. To the same creature just passing through, the same surface layout is simply an obstacle to locomotion. To a different creature with different dynamic action capabilities ... the same surface layout might afford sheltering. Regardless of the particular circumstances, it is the affordance that is perceived. (Carello, 1993, p. 126)

The concept of affordances is, then, a way of describing an environment that is scaled to a perceiver and that entails meaning (Carello, 1993, pp. 126-127). Affordances do not exist in a vacuum. They exist only by virtue of there being subjects to perceive them. This is not to say that objects do not have real physical properties. It is, rather, that what we perceive as their affordances for us are characteristics that respond to intentionalities or projects of our own. Projects may range from the mundane task of satisfying hunger or thirst to the culturally more ambitious tasks of attracting mates, asserting individual or collective identities, and the like. In a variation of phenomenology's core insight that consciousness is always consciousness of, ecological psychology suggests that meaning neither preexists nor is constituted by a subject. It emerges in and through the practices by which interpretive organisms interact with their worlds.

In lived situations, for Gibson, the affordances of objects become constrained by the effectivities or action capabilities of agents or subjects. In turn, the effectivities of subjects are constrained by the affordances of the objects encountered (Ingold, 1992, p. 46). The use of the terms subject and object here should also be seen as relational and situated: What is an object to a particular subject can also be a subject perceiving the other as an object. Objectivity and subjectivity are not pregiven but are reciprocally constituted through enacted relations. Animals, however, live in shared environments consisting of inanimate, animate, and socialized objects or actors. Inanimate objects afford possible actions; animate objects afford interactions; and socialized objects, which include humans but also nonhuman animals, afford proper actions and interactions - that is, interactions constrained or mediated by the "perceived need to present proper affordances to the other" (Reed, 1988, p. 121). According to Gibsonian interpreter Edward Reed (1988), socialization is thus "a natural consequence of our living in a populated, animate environment, full of affordances" (p. 117); it is

a consequence of the fact that social animals are aware of the affordances around them in a shared way, in a way that recognizes both commonalities and differences for different observers in the values of objects, places and events. . . Human sociality is in this sense natural, having evolved as a refinement of our perceptions of, and action within, the environment. (pp. 121-123)

Both Reed (1988) and Ingold (1992, 1995, 2000), two influential interpreters of Gibson, suggest that sociality precedes language and cultural interpretation. Thus, a Gibsonian perspective would be compatible with the view more common in the social sciences (following the "cultural" or "linguistic turn") that language mediates our thinking and interpretation, "disclosing" the world for us, in Martin Heidegger's terms, and making our perception of the world possible. In either case, for Reed and Ingold, language and conceptual thought, like tools, transform the perception of the environment and "enlarge the effectivities of their users" (Ingold, 1992, p. 46). As the world offers affordances for various possible actions, interac- 
tions, and proper actions, so it also affords socially sustained affordances or interpretive possibilities that are taken up through and within linguistic practices and traditions that develop over time. ${ }^{8}$ For Ingold (1992), this engagement between persons and environments involves a mutual process of "production" or "bringing forth," and "consumption" or "taking up": People create their environments "in the sense that the environment is the embodiment of past activity" (p. 50), shaped by the ways it has been appropriated and negotiated within the life-worlds of its inhabitants. As production is a becoming of the environment through the active labor of social beings, so consumption is a becoming of persons. In Ingold's usage, the terms production and consumption are intended to evoke not a reductively productivist metaphysic but rather the notion of metabolism at its broadest-the mutual exchange of not only nutrients but meanings.

The Gibsonian theory of direct perception, then, like the enactive biology of cognition, presupposes that life and perceptual activity are given in engagement and immersion in a world of affordances and effectivities - a world populated by subjectively active and animate others - and not in a disengaged representation and cognitive organization of data that has been somehow extracted from the world. This view of humans as living and acting within larger relational networks suggests an intermeshing of the natural and the cultural. To use Latour's (1999) preferred terms, the world consists of natural-cultural "collectives" (pp. 193ff). The compatibility between ANT and these latter approaches should at this point become more apparent. Although ANT's agents are in principle "radically indeterminate" (Callon, 1999, p. 181), their ontological status unknowable prior to the interactive "network building" being examined, they do not begin as undifferentiated tabulae rasae. Rather, as Callon (1999) argues in his actor-network account of the economic market, they are always already "caught up in a network of relations, in a flow of intermediaries that circulate, connect, link and reconstitute identities" (p. 187). The economic market network, according to Callon, is constructed precisely through the disembedding and "disentangling" of entities and the "framing" of some as calculative agents and others as commodities. Particular forms of subjectivity and objectivity are thereby created not ex nihilo but out of already networked relations consisting of what can best be described as an "original hybridity" of subjectivities, materialities, affordances, and effectivities.

\section{FILLING UP: TRANSLOCAL CULTURAL- ECOLOGICAL NETWORK INTERACTIONS}

To understand a world of multiple and overlapping actor networks, however, requires the ability to make relevant distinctions between these collectives, a task at which ANT, even by Latour's own admission, has had difficulty (Latour, 1996b, p. 380; see also Landstrøm, 1998, p. 63). The study and comparison of different cultures has traditionally been the hallmark of cultural anthropology, and the relationship between cultural systems and their ecological environments has, in previous decades, been the explicit focus of cultural ecology, cultural materialism, and systems-based ecological anthropology. Since the 1970s, these approaches have been critiqued for their residual functionalism, their reductionist or environmental determinist tendencies, their static ideas of ecosystems, and their almost exclusive concern with bounded local settings, considered outmoded in a world where the local is increasingly shaped and influenced by translocal and global processes. More generally, their positivist orientation has been eclipsed by the broader interest in interpretive, postmodernist/poststructuralist, and political economic approaches. 
The past decade or so, however, has seen a remarkable efflorescence of work by anthropologists (and increasingly sociologists, archaeologists, and others) grappling once again with nature, ecology, and the environment. Scholars have brought with them a series of new tools, including discourse analysis, dialectical methods, and poststructuralist and postcolonialist forms of self-reflexivity. A "new environmental anthropology" (Kottak, 1999) has been emerging, alongside critical reconsiderations of the earlier cultural-ecological theories (Biersack, 1999; Milton, 1996), which call for more sophisticated "biocultural syntheses" (A. H. Goodman \& Leatherman, 1998) and engagements with the various new ecologies including nonequilibrium biological ecology (Zimmerer, 1994, 2000), symbolic ecology (Descola \& Pálsson, 1996), historical ecology (Crumley, 1994), and political ecology (Peet \& Watts, 1996). Although it is difficult to summarize this broad and rapidly evolving discourse, several thematic strands are clearly evident. Most of these efforts attempt to theorize what is sometimes loosely called the culture of naturethat is, the ways in which human cultural groups both symbolically represent and materially interact with and transform the nonhuman world. At the same time, the simple dualist model of culture/nature is rejected by many of these researchers as ethnocentric, a product of Western modernity, and thus inapplicable to societies that may not conceive of such a dichotomy at all (e.g., Descola \& Pálsson, 1996). Following the broader contours of recent cultural anthropology, much of this work also emphasizes practice, the formation of group identities and collective movements, and cultural change and interaction in the context of larger scale processes such as globalization. One thread of this research, then, has been the traditionally anthropological endeavor of cultural comparison, in this case, the comparison of different cultures of nature, nature-cultures, or ethnoecologies. But another has been a clear desire to focus on the struggles faced by specific cultural groups within larger translocal processes. Let us call these the comparative and the translocalcontextualizing moments of cultural-ecological research.

Drawing on the ideas introduced earlier, we can consider both cultures and ecologies to be not some essential, bounded wholes but at best only analytically distinguishable moments within the fluid activity of network building. Through their various practices, cultural groups appropriate, symbolize, and transform the affordances presented by their environments and in the process construct spaces, landscapes, environments, natures, and ecologies. Neither of these major analytical categories-culture, nature-is bounded or static. They productively interact and intermesh, change over time, and are internally differentiated. Cultures, for instance, are dynamic and mutable. They are processes, consisting of a plurality of subjectivating entities, whose identities are shaped in and through ongoing relations enacted with others and with environments. Environments, also, do not preexist those for whom they serve as environments. The very idea of an environment (like that of ecology and nature) should be seen as a relational function, constituting no more than a mutable element within a figure-ground relational field.

For the purposes of the model I am developing, it would seem important to look for regularities in cultural-ecological network building. This would allow us both to compare cultural-ecological practices (the first moment mentioned above) and to contextualize these within broader translocal and global processes (the second). Perhaps the easiest move to make at this juncture would be to simply assert a radical difference between premodern and modern cultures. Although the former had adapted more or less successfully to their local environments, the latter has mobilized itself (with the aid of science, technology, capitalism, and so on) to break out 
of any ecological constraints and wreak havoc around the planet. This is the approach sometimes taken, at least implicitly, within the earlier generation of cultural ecology, and one that still finds favor among many environmentalists. But it is one that is by and large rejected by most cultural anthropologists today. Latour's (1993) response to such an argument is useful to consider. Stressing the continuity between collectives, he wrote,

All nature-cultures are similar in that they simultaneously construct humans, divinities and nonhumans. . . All of them sort out what will bear signs and what will not. If there is one thing we all do, it is surely that we construct both our human collectives and the nonhumans that surround them. In constituting their collectives, some mobilize ancestors, lions, fixed stars, and the coagulated blood of sacrifice; in constructing ours, we mobilize genetics, zoology, cosmology and hæmatology. (p. 106)

Rather than seeing this difference as a liberation from superstition into the clear light of objective science- a shift that puts us safely on the advance side of the culture-nature divide and leaves them tottering behind on the other-Latour (1999) argued that what distinguishes so-called modern society is simply that it "translates, crosses over, enrolls, and mobilizes more elements that are more intimately connected, with a more finely woven social fabric" and with "a deepened intimacy, a more intricate mesh" between society and technology (pp. 195-196). In other words, the distinction is to be found in the size, scale, length, and complexity of the networks.

Others, however, seek to define a more qualitative difference between competing networks. In his overview of "the manifold forms that the natural takes in today's world" (Escobar, 1999, p. 1), Escobar (1999) identified three distinct "regimes of nature" - three "articulations" of "the historical and the biological"which he names "organic nature," "capitalist nature," and "technonature." He proposed that each of these can be more appropriately studied through a particular form of knowledge: "organic nature through the anthropology of local knowledge, capitalist nature in terms of historical materialism, and technonature from the perspective of science-and-technology studies" (p. 5). Although Escobar acknowledged that two of the three regimes (organic nature, which he associates with rural and traditional communities, and hybrid technonature) do not recognize an ontological separation between nature and society and that the three regimes overlap and intertwine on multiple levels in practice, nevertheless, by calling them regimes of nature, he appears to presume an underlying nature that preexists its own construction within these regimes-a nature that is biophysical but one that is not always already a hybrid collective of material, organic-animate, artifactual, and discursive elements (see Milton, 1999). Despite the usefulness of his categories, then, the purity of a preexisting nature untouched by human culture remains.

Parajuli's (1998) notion of "ecological ethnicities" comes closer to articulating the impossibility of "purifying" nature from its cultural domains. He intended that term to represent peasant and marginalized communities for whom identity is intimately tied, in fact embedded, within specific relations with the natural worldgroups for whom "ethnicity" is "informed and defined by the ways in which its umbilical cord is unevenly tied to the motion of global capital" (p. 188). His focus on marginalized communities, and specifically on those he calls "ecosystem people," unfortunately repeats the trope by which "we moderns" are considered to have "science," whereas "they" (premoderns, ecosystem people) have "ethno-sciences." 
But the splicing together of the terms ecological and ethnicity provides a useful move that could follow a more symmetrical path, that is, a path that includes all ethnicities, cultures, or identities (or all sciences, both dominant/Western and traditional indigenous ones) under the same categorical rubric - as ethnoecologies, ethnosciences, and so on (see, e.g., Hviding, 1996; Kuletz, 1998).

\section{MULTICULTURAL ECOLOGIES}

To make this point more explicit, I propose the concept of multicultural ecologies. This suggests that all ecologies (except perhaps those not involving humans or other social animals) are fluidly and pluralistically cultural, not only in the sense that they are constructed as ideas and discourses but also in the sense that they are shaped and enacted in and through various kinds of cultural and material practices. Just as the term ecology refers both to a scientific practice and to a more general sense of interconnected relational webs, so multicultural ecology can refer to a theoretical and applied research practice, whereas multicultural ecologies would be the variously ordered animate relational networks enacted in a given geographical locale or in the world at large. The apparent tension between the two terms, with the first suggesting a relativistic culturalism and the second a scientific realism, can be considered a productive tension: the relativism of multiculturalism delimits the imperial tendencies of uncritically applied science, whereas the realism of ecology points toward a material anchor for the former term. Such a multicultural ecology would recognize the nonessentialist, processual, and dialogical nature of culturalecological interaction, which is always embedded within significatory and discursive practices and materially embodied ecological relations (cf. Foster \& Burkett, 2000; Salleh, 2001). At the same time, it would recognize that there are relative stabilities, "knots" and "nodes" tying together different networks, and levels of enaction that are more encompassing, in scale and in scope, than others.

Recent work under the rubric of political ecology has been especially insistent on examining the interconnection between large-scale and more locally embedded social and ecological processes - that is, between what ANT would consider longer or more extended networks and those that are shorter. More extensive networkbuilding activities, such as those represented by modernization or economic and cultural globalization, have increased the tendency for cultural-ecological networks to interact and mutually modify and transform each other, leading to the increased destabilization of formerly established ones. In the process, certain such networks have tended to dominate or even suffocate others, while others have become nested within larger ones, changing in specific ways while retaining structural characteristics in the process. The incorporation of developing countries into the world economy, for instance, involves a set of processes by which existing social and ecological relations are disentangled and their elements are reterritorialized into the production of new actors and new network relations (such as private property, cash crop agriculture, the emergence of local or state elites, transnational corporations, international agencies). In the process, some of the previously existing network relations (e.g., subsistence farming, unwritten collective understandings about access to land) may be more subject to disentanglement than others (e.g., patterns of male domination, power relations among tribal groups), with the latter persisting in various forms. Where social movements emerge to resist the new networks, they in turn may give rise to alternative translocal networks connecting the interests of local groups with those of transnational actors such as 
nongovernmental organizations (e.g., Brosius, 1999). These competing networks involve not only social groups vying for power but cultural-ecological practices (subsistence versus cash crop farming), technical apparatuses (media, arms, schools), and other kinds of material, semiotic, and animate actants.

An analysis of any such complex sets of transformations is bound to raise political questions at various junctures-questions such as "What is gained and what is lost, who is heard and who is silenced" (Brosius, 1999, p. 16). Political ecology, like all critical social science, includes among its goals the clarification of the political stakes for different actors in a conflict, examining the ways in which institutions and social groups vie for power, contest meanings, and so on. I referred earlier to the criticism that ANT is not capable of providing normative or critical tools for social analysis. Through an alignment with such approaches as political ecology, ANT has the potential of providing more fine-tuned analyses of how networks come to be constructed, contested, and resisted, at a range of scales. ANT has raised questions about the identities of the constructors and resisters; Michel Callon's (1986) analysis of the domestication of scallops in St. Brieuc Bay, for instance, portrayed scallops as resisting their attempted enrollments by fishermen and scientists. The notion of animacy, as presented above, would seem to suggest that scallops can indeed be resisters but that door closers (of the hinge, spring, or hydraulic type) perhaps cannot, because scallops act on the affordances they perceive around them, whereas door closers do not (see Johnson, 1988). Both, however, can be enrolled into networks by human social groups, and both, in turn, raise political questions. These include questions about humans (for instance, who has power to make decisions) and about nonhumans (for instance, about whether scallops, whales, cyborgs, or fetuses—see Casper, 1994—should be considered agents and granted one or another kind of consideration in human decisions). Such questions have generally been deferred, heretofore, by assuming a fixed ontological divide between humans and nonhumans, but their continued deferral would seem to be unreasonable not only for the sake of the nonhumans but for the sake of understanding our entanglements with them.

In the end, if agency (or animacy) is not some fixed property carried by some entities and not by others, if it is instead a circulating quality or force by which relations are enacted, then the normative criterion that most readily suggests itself is this one: that the networks we coconstruct be such that agency/animacy can circulate freely, not be fixed and confined within rigid hierarchies of who is heard and who is silenced, who issues orders and who is to carry those orders out. An ethic of circulating agency, then, is one of dialogue, relationality, and, in one sense or another, participatory democracy - an expansive democracy that includes various kinds of actors, some of whom vote in elections, others who vote with their feet (or fins), and others who enter silently into contracts but who alter those contracts in the process.

If, as Latour (1993) argued, all collectives "are similar in that they simultaneously construct humans, divinities and nonhumans," these are constructed out of existing relations and they channel and "territorialize" (to use Deleuze \& Guattari's [1987] term) agency and animacy into specific conduits. As cultural-ecological relations are reinscribed and reconfigured into ever more global networks, we must ask questions about how they reconfigure agency (among humans, at least) and animacy (among all of us, humans and nonhumans alike). The globalizing economy of consumer capitalism disentangles previously existing cultural-ecological relations, reincorporating their parts into networks in which, as Castree (2002) 
argued, "some agents have far more capacity to direct the course of socionatural relations than do others." This asymmetry derives from the ability of some "to "collect' power and condense it" through the "immutable mobile" of money, a powerful medium "for capturing the agencies and powers of human and nonhuman others" and for compelling these others to act as the intermediaries of the former (p. 141). A full-fledged analysis of capitalism is beyond the scope of this article, but what I am suggesting is that the differences between nature-culture collectives can be evaluated-not from a relativist perspective that sees all cultural practices as equally valid (because there is no natural standard by which to measure cultural adaptiveness or appropriateness), nor from a crudely adaptationist one (according to which groups merely adapt to, rather than transform, preexisting environments or ecological niches). Rather, they can be evaluated from a perspective of the world as coconstituted by the relational activities of multiple and heterogeneous actors or actants, whose animate relations are reconfigured in every network-building encounter. Inevitably, because the interaction between different and differently positioned networks is a matter that involves the circulation of agency (alongside power, subjectivity, and desire), the study of these necessarily involves ethical judgment because the researcher is likely to be implicated, on some level, within the object of study.

To conclude, then, in light of the realist-constructivist debate, I have tried here to suggest some theoretical resources for rethinking and challenging the dichotomy of nature and culture. Situating this debate within the long-standing modernist tradition of categorically distinguishing nature from culture and subject from object, I have suggested that a nondualistic space of provisional neutrality, necessary for the task of rethinking nature/culture, could be gleaned from the efforts of actornetwork theorists but that these efforts leave certain gaps that need to be addressed otherwise. The gaps in theorizing agency and macro-scale cultural-ecological interactions are being addressed in potentially compatible research programs (e.g., political ecology, environmental anthropology). I hope, however, through linking concepts such as animacy and multicultural ecology with ANT, to have suggested a few new points of connection and compatibility. Also, I hope to have demonstrated that there is an important normative dimension associated with the notion of agency and animacy, particularly as it is recognized that these circulate within all relational networks. Although I have suggested how these concepts can enrich the understanding of environmental issues, future research devoted to their deeper integration and development and to the understanding of their normative implications is necessary.

\section{NOTES}

1. On nature and the constructivist-realist debate, see Bird (1987), Wilson (1991), Evernden (1992), Soper (1995), Szerszynski (1996), Macnaghten and Urry (1998), Braun and Castree (1998, 2001), Peterson (1999), M. Smith (1999), and Franklin (2002).

2. More nuanced critiques appeared in the inaugural issue of Environmental History (Volume 1, Number 1, 1996). See also Rothenberg (1998) and Peterson (1999).

3. The biocentric critics of postmodernism conflate under that term a broad array of widely divergent approaches, ranging from neo-Marxist, feminist, and postcolonial (or anticolonial) theory to poststructuralist and explicitly deconstructivist or postmodernist critical strategies. For a response to their critiques, see Chaloupka (2000).

4. The argument that both nature and certain social groups (women, non-Europeans) have been discursively oppressed by Western ideas about nature has been made most forcefully by ecofeminists (e.g., Merchant, 1990; Plumwood, 1993; Shiva, 1988). Other theorists who attempt to work out a more ecologically open-ended, posthumanist, or postconstructivist 
theory include Haraway (1991, 1992), Hayles (1991, 1995), Slack and Whitt (1992), Barad (1996, 1999), and others discussed herein.

5. On actor-network theory, see Callon and Latour (1992), Callon (1986), Latour (1993, 1999), Ashmore, Wooffitt, \& Harding (1994), Bingham (1996), Murdoch (1997, 2001), Law and Hassard (1999), Michael (1996, 2000), Hetherington and Law (2000), and the actornetwork resource Web site (Lancaster University Sociology Department): http://www. comp.lancs.ac.uk/sociology/ant.html.

6. For some critiques of actor-network theory, see Collins and Yearley (1992a, 1992b), Lee and Brown (1994), Murdoch (1997), Elam (1999), Law and Hassard (1999), Hetherington and Law (2000), Albertsen and Diken (2001), Castree (2002), and Kirsch and Mitchell (2002).

7. On actor-network theory and social psychology, see Michael (1996). The literature critiquing liberal humanist identity is large, and its posthumanist alternatives are visible in a range of poststructuralist, feminist, and other critical writings; see, for example, Seidman and Nicholson (1995), Haraway (1991, 1992), Whatmore (1997), Hayles (1999), and Wolfe (1998).

8. This is a point that is not particularly taken up by Gibson, whose intent was more to challenge the subject-object dichotomy and "to put meaning back into the world, within a relational ontology" (Costall, 1995, p. 477). But it is a crucial point for us if we are to make the postmodern step of deconstructing the nature-culture dichotomy. For some elaborations on this step within the framework of ecological psychology, see Turvey and Carello (1981), Carello (1993), Barwise and Perry (1983), Costall (1995), and Sharrock and Coulter (1998).

\section{REFERENCES}

Albertsen, N., \& Diken, B. (2001). What is the social? (Draft, revised June 16, 2001). Retrieved February 2002 from the Department of Sociology, Lancaster University Web site: http://www.comp.lancs.ac.uk/sociology/soc033bd.html

Ashmore, M., Wooffitt, R., \& Harding, S. (1994). Human and others, agents and things. American Behavioral Scientist, 37, 6.

Barad, K. (1996). Meeting the universe halfway: Realism and social constructivism without contradiction. In L. Hankinson Nelson \& J. Nelson (Eds.), Feminism, science, and the philosophy of science (pp. 161-194). Dordrecht, the Netherlands: Kluwer.

Barad, K. (1999). Agential realism: Feminist interventions in understanding scientific practices. In M. Biagioli (Ed.), The science studies reader (pp. 1-11). New York: Routledge.

Barwise, J., \& Perry, J. (1983). Situations and attitudes. Cambridge, MA: MIT Press.

Biersack, A. (1999). Introduction: From the "new ecology" to the new ecologies. American Anthropologist, 101(1), 5-18.

Bingham, N. (1996). Object-ions: From technological determinism towards geographies of relations. Environment and Planning D: Society and Space, 14, 635-657.

Bird, E. A. R. (1987). The social construction of nature: Theoretical approaches to the history of environmental problems. Environmental Review, 11, 255-264.

Braun, B., \& Castree, N. (Eds.). (1998). Remaking reality: Nature at the millenium. New York: Routledge.

Braun, B., \& Castree, N. (Eds.). (2001). Social nature: Theory, practice, politics. Oxford, UK: Blackwell.

Brosius, J. P. (1999). Green dots, pink hearts: Displacing politics from the Malaysian rain forest. American Anthropologist 101(1), 36-57.

Busch, L., \& Juska, A. (1997). Beyond political economy: Actor-networks and the globalization of agriculture. Review of International Political Economy 4(4), 688-708.

Callicott, J. B. (1991). The wilderness idea revisited: The sustainable development alternative. Environmental Professional, 13, 235-247.

Callon, M. (1986). Some elements in a sociology of translation: Domestication of the scallops and fishermen of St Brieuc Bay. In J. Law (Ed.), Power, action and belief: A new 
sociology of knowledge? (Sociological Review Monographs, No. 32, pp. 196-233). London: Routledge Kegan Paul.

Callon, M. (1999). Actor-network theory-The market test. In J. Law \& J. Hassard (Eds.), Actor network theory and after. Oxford, UK: Blackwell.

Callon, M., \& Latour, B. (1992). Don't throw the baby out with the Bath school! A reply to Collins and Yearley. In A. Pickering (Ed.), Science as practice and culture. Chicago: University of Chicago Press.

Carello, C. (1993). Realism and ecological units of analysis. In D. Steiner \& M. Nauser (Eds.), Human ecology: Fragments of anti-fragmentary views of the world. New York: Routledge.

Casper, M. J. (1994). Reframing and grounding nonhuman agency. American Behavioral Scientist, 37(6), 839-856.

Castree, N. (2002). False antitheses? Marxism, nature and actor-networks. Antipode, 34(1), 111-146.

Chaloupka, W. (2000). Jagged terrain: Cronon, Soulé, and the struggle over nature and deconstruction in environmental theory. Strategies, 13(1), 23-39.

Collins, H., \& Yearley, S. (1992a). Epistemological chicken. In A. Pickering (Ed.), Science as practice and culture (pp. 301-326). Chicago: University of Chicago Press.

Collins, H., \& Yearley, S. (1992b). Journey into space. In A. Pickering (Ed.), Science as practice and culture (pp. 369-389). Chicago: University of Chicago Press.

Costall, A. (1995). Socializing affordances. Theory and Psychology, 5(4), 467-481.

Cronon, W. (1995a, August 13). The trouble with wilderness. The New York Times, pp. $42 \mathrm{ff}$.

Cronon, W. (Ed.). (1995b). Uncommon ground: Toward reinventing nature. New York: Norton.

Crumley, C. (Ed.). (1994). Historical ecology: Cultural knowledge and changing landscapes. Santa Fe, NM: School of American Research Press.

Crumley, C. (Ed.). (2001). New directions in anthropology \& environment. New York: AltaMira Press.

Deleuze, G., \& Guattari, F. (1987). A thousand plateaus (B. Massumi, Trans.). Minneapolis: University of Minnesota Press.

Descola, P., \& Pálsson, G. (Eds.). (1996). Nature and society: Anthropological perspectives. New York: Routledge.

Eden, S., Tunstall, S., \& Tapsell, S. (2000). Translating nature: River restoration as natureculture. Environment and Planning D: Society and Space, 18, 257-273.

Elam, M. (1999). Living dangerously with Bruno Latour in a hybrid world. Theory, Culture \& Society, 16(4), 1-24.

Ellen, R., \& Fukui, K. (Eds.). (1996). Redefining nature: Ecology, culture and domestication. Oxford, UK: Berg.

Escobar, A. (1999). After nature: Steps to an antiessentialist political ecology. Current Anthropology, 40, 1-30.

Evernden, N. (1992). The social creation of nature. Toronto, Canada: University of Toronto Press.

Foreman, D. (1996/1997). All kinds of wilderness foes [Editorial]. Wild Earth, 6(4), 1-4.

Foster, J. B., \& Burkett, P. (2000). The dialectic of organic/inorganic relations: Marx and the Hegelian philosophy of nature. Organization \& Environment, 13(4), 403-425.

Franklin, A. (2002). Nature and social theory. London: Sage.

Geertz, C. (1973). The interpretation of cultures. New York: Basic Books.

Gibson, J. J. (1979). The ecological approach to visual perception. Boston: Houghton Mifflin.

Gibson, J. J. (1982). Reasons for realism: Selected essays of James J. Gibson (E. Reed \& R. Jones, Eds.). Hillsdale, NJ: Lawrence Erlbaum.

Gieryn, T. F. (1999). Cultural boundaries of science: Credibility on the line. Chicago: University of Chicago Press. 
Goodman, A. H., \& Leatherman, T. L. (Eds.). (1998). Building a new biocultural synthesis: Political-economic perspectives on human biology. Ann Arbor: University of Michigan Press.

Goodman, D. (2001). Ontology matters: The relational materiality of nature and agro-food studies. Sociologia Ruralis, 41(2), 182-200.

Gross, P. R., \& Levitt, N. (1994). Higher superstition: The academic Left and its quarrels with science. Baltimore: Johns Hopkins University Press.

Gross, P. R., Levitt, N., \& Lewis, M. (Eds.). (1996). The flight from science and reason. New York: New York Academy of Sciences.

Haraway, D. (1991). Simians, cyborgs, and women: The reinvention of nature. New York: Routledge.

Haraway, D. (1992). The promises of monsters: A regenerative politics for inappropriate/d others. In L. Grossberg, C. Nelson, \& P. Treichler (Eds.), Cultural studies. New York: Routledge.

Hayles, N. K. (1991). Constrained constructivism: Locating scientific inquiry in the theatre of representation. New Orleans Review, 18, 76-85.

Hayles, N. K. (1995). Searching for common ground. In M. Soulé \& W. Lease (Eds.), Reinventing nature? Responses to postmodern deconstruction. Washington, DC: Island Press.

Hayles, N. K. (1999). How we became posthuman: Virtual bodies in cybernetics, literature and informatics. Chicago: University of Chicago Press.

Hetherington, K., \& Law, J. (2000). After networks. Environment and Planning B: Society and Space, 27, 127-132.

Horigan, S. (1988). Nature and culture in Western discourses. New York: Routledge.

Hviding, E. (1996). Nature, culture, magic, science: On meta-languages for comparison in cultural ecology. In P. Descola \& G. Pálsson (Eds.), Nature and society: Anthropological perspectives (pp. 165-184). New York: Routledge.

Ingold, T. (1992). Culture and the perception of the environment. In E. Croll \& D. Parkin (Eds.), Bush base, forest farm: Culture, environment and development. London: Routledge.

Ingold, T. (1995). Building, dwelling, living: How animals and people make themselves at home in the world. In M. Strathern (Ed.), Shifting contexts: Transformations in anthropological knowledge (pp. 57-80). London: Routledge.

Ingold, T. (2000). The perception of the environment: Essays in livelihood, dwelling, and skill. London: Routledge.

Johnson, J. (1988). Mixing humans and nonhumans together: The sociology of a doorcloser. Social Problems, 35(3), 298-310.

Kirsch, S., \& Mitchell, D. (2002, March 23). "Purely atomic": Dead labor, non-human actors, and the agency of scientific work. Paper presented at the Association of American Geographers conference, Los Angeles.

Kottak, C. P. (1999). The new ecological anthropology. American Anthropologist, 101(1), 23-25.

Kuletz, V. (1998). The tainted desert: Environmental and social ruin in the American West. New York: Routledge.

Landstrøm, C. (1998). The man that freed the non-humans (interview with Bruno Latour). Vest, 11(1), 61-64.

Latour, B. (1988). The pasteurization of France. Cambridge, MA: Harvard University Press.

Latour, B. (1993). We have never been modern. Cambridge, MA: Harvard University Press.

Latour, B. (1996a). Aramis, or the love of technology. Cambridge, MA: Harvard University Press.

Latour, B. (1996b). On actor-network theory: A few clarifications. Soziale Welt, 47, 369-381.

Latour, B. (1999). Pandora's hope: Essays on the reality of science studies. Cambridge, MA: Harvard University Press.

Latour, B., \& Crawford, T. H. (1993a). An interview with Latour. Configurations, 2, 247-269. 
Laurier, E., \& Philo, C. (1999). X-morphising: A review essay of Aramis. Environment and Planning A, 31, 1047-1073.

Law, J. (1999). After ANT: Complexity, naming and topology. In J. Law \& J. Hassard (Eds.), Actor network theory and after (pp. 1-14). Oxford, UK: Blackwell.

Law, J., \& Hassard, J. (Eds.). (1999). Actor network theory and after. Oxford, UK: Blackwell.

Lee, N., \& Brown, S. (1994). Otherness and the actor network: The undiscovered continent. American Behavioral Scientist, 37, 772-790.

Levins, R., \& Lewontin, R. (1985). The dialectical biologist. Cambridge, MA: Harvard University Press.

Lewontin, R. C. (1982). Organism and environment. In H. C. Plotkin (Ed.), Learning, development, and culture (pp. 151-170). New York: Wiley.

Macnaghten, P., \& Urry, J. (1998). Contested natures. London: Sage.

Maturana, H., \& Varela, F. (1980). Autopoiesis and cognition: The realization of the living. In R. S. Cohen \& M. W. Wartofsky (Eds.), Boston studies in the philosophy of science (Vol. 42). Dordrecht, Holland: D. Reidel.

Maturana, H. R., \& Varela, F. J. (1987). The tree of knowledge: The biological roots of understanding. Boston: Shambhala.

McGrane, B. (1989). Beyond anthropology: Society and the other. New York: Columbia University Press.

Merchant, C. (1990). The death of nature: Women, ecology, and the scientific revolution. San Francisco: Harper \& Row.

Merchant, C. (1998). The death of nature: A retrospective. Organization \& Environment, 11(2), 198-206.

Michael, M. (1996). Constructing identities: The social, the nonhuman, and change. London: Sage.

Michael, M. (2000). Reconnecting culture, technology and nature. London: Routledge.

Milton, K. (1996). Environmentalism and cultural theory. New York: Routledge.

Milton, K. (1999). Response to Escobar, “After Nature.” Current Anthropology, 40, 21-22.

Mol, A. (1999). Ontological politics: A word and some questions. In J. Law \& J. Hassard (Eds.), Actor network theory and after. Oxford, UK: Blackwell.

Moore, J. W. (2000). Environmental crises and the metabolic rift in world-historical perspective. Organization \& Environment, 13(2), 123-157.

Murdoch, J. (1997). Inhuman/nonhuman/human: Actor-network theory and the prospects for a nondualistic and symmetrical perspective on nature and society. Society and Space, $15,731-756$.

Murdoch, J. (2001). Ecologising sociology: Actor-network theory, co-construction and the problem of human exemptionalism. Sociology, 35, 1.

Nelson, M. P. (1996). Rethinking wilderness: The need for a new idea of wilderness. Philosophy in the Contemporary World, 3, 2.

Oyama, S. (2000). The ontogeny of information (2nd ed.). Durham, NC: Duke University Press.

Parajuli, P. (1998). Beyond capitalized nature: Ecological ethnicity as an arena of conflict in the regime of globalization. Ecumene, 5(2), 186-217.

Parker, G., \& Wragg, A. (1999). Networks, agency and (de)stabilization: The issue of navigation on the River Wye, UK. Journal of Environmental Planning and Management, 42(4), 471-487.

Peet, R., \& Watts, M. (Eds.). (1996). Liberation ecologies: Environment, development, social movements. New York: Routledge.

Peterson, A. (1999). Environmental ethics and the social construction of nature. Environmental Ethics, 21, 339-357.

Plumwood, V. (1993). Feminism and the mastery of nature. London: Routledge.

Redclift, M., \& Woodgate, G. (Eds.). (1998). The international handbook of environmental sociology. Cheltenham, UK: Edward Elgar. 
Reed, E. S. (1988). The affordances of the animate environment: Social science from the ecological point of view. In T. Ingold (Ed.), What is an animal? London: Unwin Hyman.

Rothenberg, D. (1998). With friends like these, wilderness needs no enemies. Research in Philosophy and Technology, 17, 343-351.

Salleh, A. (2001). Sustaining Marx or sustaining nature? An ecofeminist response to Foster and Burkett. Organization \& Environment, 14(4), 443-450.

Sanders, J. T. (1999). Affordances: An ecological approach to first philosophy. In G. Weiss \& H. F. Haber (Eds.), Perspectives on embodiment: The intersections of nature and culture. New York: Routledge.

Seidman, S., \& Nicholson, L. (Eds.). (1995). Social postmodernism: Beyond identity politics. Cambridge, UK: Cambridge University Press.

Serres, M. (1981). The parasite. Baltimore: Johns Hopkins University Press.

Sessions, G. (1995a). Political correctness, ecological realities and the future of the ecology movement. Trumpeter, 12(4), 191-196.

Sessions, G. (1995b). Postmodernism and environmental justice: The demise of the ecology movement? Trumpeter, 12(3), 150-154.

Sessions, G. (1996). Reinventing nature, the end of wilderness? A response to William Cronon's Uncommon Ground. Trumpeter, 13(1), 33-38.

Sharrock, W., \& Coulter, J. (1998). On what we can see. Theory \& Psychology, 8(2), 147-164.

Shepard, P. (1995). Virtually hunting reality in the forests of simulacra. In M. Soulé \& G. Lease (Eds.), Reinventing nature? Responses to postmodern deconstruction (pp. 1729). Washington, DC: Island Press.

Shiva, V. (1988). Staying alive: Women, ecology, and development. London: Zed Books.

Slack, J. D., \& Whitt, L. A. (1992). Ethics and cultural studies. In L. Grossberg, C. Nelson, \& P. Treichler (Eds.), Cultural studies. New York: Routledge.

Smith, M. (1999). To speak of trees: Social constructivism, environmental values, and the future of deep ecology. Environmental Ethics, 21, 359-376.

Snyder, G. (1996/1997). Nature as seen from Kitkitdizze is no "social construction." Wild Earth, 6(4), 8-9.

Snyder, G. (1998). Is nature real? Resurgence, 190, 32.

Soper, K. (1995). What is nature? Oxford, UK: Blackwell.

Soulé, M. (1995). The social siege of nature. In M. Soulé \& G. Lease (Eds.), Reinventing nature? Responses to postmodern deconstruction (pp. 137-170). Washington, DC: Island Press.

Soulé, M., \& Lease, G. (Eds.). (1995). Reinventing nature? Responses to postmodern deconstruction. Washington, DC: Island Press.

Steiner, D., \& Nauser, M. (Eds.). (1993). Human ecology: Fragments of anti-fragmentary views of the world. London: Routledge.

Swyngedouw, E. (1999). Modernity and hybridity. Annals of the Association of American Geographers, 89, 443-465.

Szerszynski, B. (1996). On knowing what to do: Environmentalism and the modern problematic. In S. Lash, B. Szerszynski, \& B. Wynne (Eds.), Risk, environment, and modernity. London: Sage.

Turvey, M. T., \& Carello, C. (1981). Cognition: The view from ecological realism. Cognition, 10, 313-321.

Varela, F. J., Thompson, E., \& Rosch, E. (1991). The embodied mind: Cognitive science and human experience. London: MIT Press.

Vogel, S. (2002). Environmental philosophy after the end of nature. Environmental Ethics, 24(1), 23-39.

von Uexküll, J. (1957). A stroll through the worlds of animals and men: A picture book of invisible worlds. In C. H. Schiller (Ed.), Instinctive behaviour: The development of a modern concept. New York: International Universities Press.

Whatmore, S. (1997). Dissecting the autonomous self: Hybrid cartographies for a relational ethics. Environment and Planning D: Society and Space, 15, 37-53. 
Whatmore, S. (1999). Hybrid geographies: Rethining the "human" in human geography. In D. Massey, J. Allen, \& P. Sarre (Eds.), Human geography today (pp. 22-39). London: Polity.

Wilson, A. (1991). The culture of nature: North American landscape from Disney to the Exxon Valdez. Toronto, Canada: Between the Lines.

Wolfe, C. (1998). Critical environments: Postmodern theory and the pragmatics of the outside. Minneapolis: University of Minnesota Press.

Zimmerer, K. S. (1994). Human geography and the "new ecology": The prospect and promise of integration. Annals of the Association of American Geographers, 84(1), 108-125.

Zimmerer, K. S. (2000). The reworking of conservation geographies: Nonequilibrium landscapes and nature-society hybrids. Annals of the Association of American Geographers, 90(2), 356-369. 